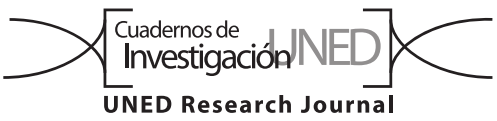

\title{
Absence of a molecular structural effect on the thermodynamic properties of several biodiesel materials
}

\author{
Hermes R. Alvarado-Montero, Carmen Monge-Montero, María Sol Vargas, Giselle Lutz \& Julio F. Mata-Segreda \\ Biomass Laboratory, School of Chemistry, University of Costa Rica. 11501-2060, Costa Rica; julio.mata@ucr.ac.cr
}

Received 23-I-2018 • Corrected 03-IV-2018 • Accepted 28-IV-2018

\begin{abstract}
In the search to develop the production of vegetable oils for non-food purposes biodiesel stands out for its great versatility as technical material and a cleaner energy technology. Physic nut (Jatropha curcas), castor-oil (Ricinus communis), oil palm (Elaeis guineensis), wine palm (Attalea butyracea) and macaw palm (Acrocomia aculeata) were chosen for study in our laboratory, because they are oleaginous plants with convenient oil yields to produce biodiesel. No significant effect from the nature of fatty-acid chains in biodiesel is observed on thermodynamic properties such as heat of combustion, cubic-expansion thermal coefficient, isothermal compressibility, enthalpy of vaporisation and Hildebrand solubility parameter. Activation energies for viscous flow of biodiesels correlates with the same property of their vegetable oil feedstocks.
\end{abstract}

Key words: biodiesel, thermodynamic properties, kinematic viscosity, Acrocomia aculeate, Attalea butyracea, Elaeis guineensis, Glycine max, Jatropha curcas, Ricinus communis.

Low oil prices are certainly good news for non-petroleum-producing economies and for high energy consumers but, an undesirable consequence is the growth in carbon emissions associated to its use. Low fossil-fuel prices could discourage further innovation and adoption of cleaner energy technologies, but nevertheless it is tenable the need to look for competitive green alternatives, where biodiesel stands out for its great versatility as technical material (Knothe, Dunn \& Bagby, 1997). There is a manifested interest in Costa Rica to develop the production of vegetable oils for non-food purposes, initiatives that come from government as well as private sector.

Physic nut (Jatropha curcas), castor-oil (Ricinus communis), oil palm (Elaeis guineensis), wine palm (Attalea
RESUMEN: Ausencia de un efecto estructural molecular sobre las propiedades termodinámicas de varios materiales tipo biodiesel. En la búsqueda de desarrollar la producción de aceites vegetales para fines no alimenticios, el biodiesel se destaca por su gran versatilidad como material técnico y como una tecnología de energía más limpia. Tempate (Jatropha curcas), higuerilla (Ricinus communis), palma aceitera (Elaeis guineensis), palma real (Attalea butyracea) y coyol (Acrocomia aculeata) fueron elegidos para su estudio en nuestro laboratorio, porque son plantas oleaginosas con rendimientos convenientes para producir biodiesel. No se observa ningún efecto significativo de la naturaleza de las cadenas de ácidos grasos en el biodiesel sobre las propiedades termodinámicas como el calor de combustión, el coeficiente térmico de expansión cúbica, la compresibilidad isotérmica, la entalpía de vaporización y el parámetro de solubilidad de Hildebrand. Las energías de activación para el flujo viscoso de biodiesel se correlacionan con la misma propiedad de sus materias primas de aceite vegetal.

Palabras clave: biodiesel, propiedades termodinámicas, viscosidad cinemática, Acrocomia aculeata, Attalea butyracea, Elaeis guineensis, Glycine max, Jatropha curcas, Ricinus communis. butyracea) and macaw palm (Acrocomia aculeata) were chosen for study in our laboratory, because they are oleaginous plants with convenient oil yields to produce biodiesel. These species are considered in the agro-industrial initiatives indicated above.

The plants are present around the world and can grow under adverse environmental conditions and need no optimal soils. Soybean (Glycine max) is included as comparison, because its oil is widely used to produce biodiesel. The periods of initiation of oil production suggest that good agronomical techniques must yet be developed, based on simultaneous multiple-species cultivation that could start yielding economical revenue from earlier times. 
TABLE 1

Lipid production of some oil-producing plants

\begin{tabular}{lcc}
\multicolumn{1}{c}{ Species } & Lipid yield $/ \mathrm{t} \mathrm{y}^{-1} \mathrm{ha}^{-1}$ & Onset of oil production \\
Elaeis guineensis & 5,5 & 4 years \\
Attalea butyraceae & 3,0 & 5 years \\
Acrocomia aculeata & 3,0 & 5 years \\
Jatropha curcas & 1,6 & 2 years \\
Ricinus communis & $1,5-2,5$ & 6 months \\
Glycine max & 1,5 & 3 months \\
\hline
\end{tabular}

Source: Bártoli (2008), Cristancho, Hanafi, Omar y Rafii (2011), Jachmanian, Pérez Gomar, Villamil y Villamil (2009), MAG (1991), Molina, Nouel-Borges, Sánchez-Blanco, Rojas-Castellanos y Espejo (2013), Smith (2015).

Based on previous results of biodiesel properties (Castellón-Elizondo, Lutz \& Mata-Segreda, 2006), we should like to discuss the unimportance of fatty-acid chain composition on the thermodynamic properties of different biodiesel materials derived from the six vegetable oils in table 1.

Biodiesel can be used not only as liquid fuel but also as alternative industrial solvent, lubricant and as fluid for transport of mechanical or thermal energies. These potential applications imply no foreseeable consequences on occupational or environmental safety, mainly because it has proved to be biodegradable at a minimum of $80 \%$ in the open environment within a month or two (Demirbaş, 2008; Lutz, Chavarría, Arias \& MataSegreda, 2006; Sendzikiene, Makareviciene, Janulis \& Makareviciute, 2007).

The generalisations derived from this discussion are useful to achieve acceptable prediction of physical properties of biodiesel materials that have not been synthesised yet.

\section{ANALYSIS}

All methyl fatty monoesters were obtained by alkaline transesterification of the feedstock oils, as has been widely reported in the literature(see for example: Mittelbach \& Remschmidt, 2004; Alvarado-Montero, 2012; MongeMontero, 2014,). Amongst these agro-industrial possibilities, the fatty-acid chain composition differs, as shown in Table 2.

The cubic-expansion thermal coefficient $(\alpha)$ was the experimental quantity from which the isothermal compressibility coefficient $\left(\kappa_{\mathrm{T}}\right)$, the enthalpy of vaporization $\left(\Delta_{\text {vap }} H^{\circ}\right)$ and the Hildebrand solubility parameter $\left(\delta_{H}\right)$ were obtained, according to the soft-solid model for liquids (Castellón-Elizondo et al., 2006). Traditional methods were used for the evaluation of parameters such as kinematic viscosity and viscous-flow activation energy, and the enthalpy of combustion (Shoemaker \& Garland, 1968), and need not be detailed in this paper.

Cubic expansion thermal coefficient $(\alpha)$ :

$$
\alpha=\frac{1}{V}\left(\frac{\partial V}{\partial T}\right)_{p}=-\left(\frac{\partial \ln \rho}{\partial T}\right)_{p}
$$

Knowledge of the cubic expansion coefficient and isothermal compressibility of fluids is needed for the design of hydraulic equipment. The observable thermodynamic properties of materials can be understood in terms of the forces between the constituent molecules. The molecular interpretation of a provides a way to assess the system cohesivity, because stronger attractive intermolecular forces allow only small inter-particle spacing gained by thermal energy increase (temperature). This thermodynamic coefficient is easily obtained from the temperature effect on density $(\rho)$ as indicated by equation [1], in the temperature range from $18^{\circ} \mathrm{C}$ up to $33^{\circ} \mathrm{C}$.

$\alpha$ values are similar for all the cases in the set of biodiesel samples studied with average value $(8,5 \pm 0,4) \times 10^{-4} \mathrm{~K}^{-1}$. Thus, no significant volumetric differences should be expected when different types of biodiesel are subjected to identical temperature increase under constant pressure.

Biodiesel materials are mixtures of fatty esters, and as it is the case with their parent hydrocarbons, the physical properties chiefly depend on molecular size. Note that Ricinus biodiesel also conforms to this expectancy, despite the presence of a hydroxyl group attached to carbon atom 12 in the ricinoleic-acid chains. Thus, acyl 
TABLE 2

Fatty-acid chain profile of the six vegetable oils studied. Data are given as gas-chromatographic mole percentage.

\begin{tabular}{|c|c|c|c|c|c|c|c|c|c|c|c|c|c|}
\hline Oil & C8:0 & C10:0 & C12:0 & C12:1 & C14:0 & C14:1 & C16:0 & C16:1 & C18:0 & $\begin{array}{c}\text { C18:1 } \\
(9 c, 12-O H)\end{array}$ & $\begin{array}{l}\text { C18:1 } \\
(9 c)\end{array}$ & $\begin{array}{c}\text { C18:2 } \\
(9 c, 12 c)\end{array}$ & $\begin{array}{c}C 18: 3 \\
(9 c, 12 c, 15 c)\end{array}$ \\
\hline Elaeis guineensis & & & & & & & 44 & & 5,0 & & 40 & 10 & \\
\hline Jatropha curcas & & & & & & & 13 & & 7,0 & & 42 & 37 & \\
\hline Ricinus comunis & & & & & & & 3,0 & & 3,0 & 80 & 5,0 & 5,0 & \\
\hline Attalea butyracea & & & & & & & 22 & 1,0 & 1,5 & & 67 & 0,8 & 5,0 \\
\hline Acrocomia aculeate & 6,0 & 3,0 & 37 & 1,5 & 12,5 & 0,7 & 7,0 & 0,8 & 2,5 & & 19 & 2,0 & \\
\hline
\end{tabular}

TABLE 3

Thermodynamic and rheological properties of six types of methyl biodiesel.

\begin{tabular}{lcccccccc}
\multicolumn{1}{c}{ Methyl biodiesel } & $10^{4} \alpha / \mathrm{K}^{-1}$ & $\Delta_{\mathrm{vap}} \mathrm{H} / \mathrm{kJ} \mathrm{mol}^{-1}$ & $\delta_{\mathrm{H}} /\left(\mathrm{J} \mathrm{cm}^{-3}\right)^{1 / 2}$ & $\mu^{40^{\circ} \mathrm{C}} / \mathrm{mm}^{2} \mathrm{~s}^{-1}$ & $E_{\mu} / \mathrm{kJ} \mathrm{mol}^{-1}$ & $10^{10} \mathrm{~K}_{\mathrm{T}} / \mathrm{Pa}^{-1}$ & $\rho / \mathrm{g} \mathrm{cm}^{-3}\left(\mathrm{~T}^{\circ} \mathrm{C}\right)$ & $\Delta_{\mathrm{c}} \mathrm{H} / \mathrm{MJ} \mathrm{kg}^{-1}$ \\
Elaeis guineensis & $8,2 \pm 0,1$ & $106 \pm 6$ & $18,0 \pm 0,5$ & $6,97 \pm 0,05$ & $6,5 \pm 0,4$ & $7,2 \pm 0,2$ & $0,8878\left(24^{\circ} \mathrm{C}\right)$ & $36 \pm 1$ \\
Attalea butyraceae & $9,1 \pm 0,1$ & $95 \pm 1$ & $17,3 \pm 0,5$ & $4,8 \pm 0,2$ & $15,0 \pm 0,7$ & $9,1 \pm 0,3$ & $0,8881\left(22^{\circ} \mathrm{C}\right)$ & $39 \pm 1$ \\
Acrocomia aculeata & $9,1 \pm 0,1$ & $96 \pm 1$ & $17,3 \pm 0,6$ & $4,7 \pm 0,4$ & $14 \pm 1$ & $9,0 \pm 0,5$ & $0,88\left(22^{\circ} \mathrm{C}\right)$ & $38,1 \pm 0,8$ \\
Jatropha curcas & $8,3 \pm 0,2$ & $104 \pm 3$ & $17,4 \pm 0,5$ & $4,77 \pm 0,02$ & $16,1 \pm 0,5$ & $8,17 \pm 0,03$ & $0,8741\left(25^{\circ} \mathrm{C}\right)$ & $38,8 \pm 0,2$ \\
Ricinus communis & $8,2 \pm 0,1$ & $106 \pm 3$ & $17,2 \pm 0,5$ & $14,9 \pm 0,9$ & $31,6 \pm 0,6$ & $8,2 \pm 0,2$ & $0,9157\left(22^{\circ} \mathrm{C}\right)$ & $38 \pm 1$ \\
Glycine max & $8,3 \pm 0,2$ & $105 \pm 6$ & $17,5 \pm 0,3$ & $4,6 \pm 0,8$ & $17 \pm 1$ & $7,7 \pm 0,2$ & $0,871\left(24{ }^{\circ} \mathrm{C}\right)$ & $38,5 \pm 0,7$ \\
\hline
\end{tabular}

chains mainly define the degree of intermolecular interactions in biodiesel materials.

Enthalpy of vaporisation $\left(\Delta_{\text {vap }} H\right)$ : The soft-solid model for liquids proposed by our laboratory (CastellónElizondo et al., 2006), gives an inverse relation between $\alpha$ and $\Delta_{\text {vap }} H$ :

$$
\alpha=\frac{7 C_{p}}{72 \lambda \Delta_{\text {vap }} H}
$$

where $\lambda$ is a measure of the molecular packing density of the constituting particles according to their geometry (e. g., $\lambda=0,30$ for spherical molecules, $\lambda=0,62$ for rod-shaped molecules, $\lambda=1,2$ for very long hydrocarbon molecules, and $\lambda=1,4$ for triacylglycerols, as given by Lezcano-González and Mata-Segreda (2011). Readily comparison of the cohesiveness of liquids $\left(\Delta_{\text {vap }} H\right)$ can also be achieved through equation [2].

The $\Delta_{\text {vap }} H$ values are similar within experimental uncertainty (average $102 \pm 5 \mathrm{~kJ} / \mathrm{mol}$ ), and as expected, are found of the same magnitude of those of pure fatty esters of similar chain length (e. g. methyl palmitate $88 \mathrm{~kJ} /$ mol, methyl stearate $100 \mathrm{~kJ} / \mathrm{mol}$, methyl oleate $103 \mathrm{~kJ} /$ $\mathrm{mol}$, methyl linoleate $102 \mathrm{~kJ} / \mathrm{mol}$, methyl linolenate 102 $\mathrm{kJ} / \mathrm{mol}$ ). These values were obtained from the data collection of Chickos and Acree, Jr (2003). Again, the acyl chains are mainly responsible for the degree of cohesion of these systems, as is observed in figure 1 for linear chain carboxylic esters.

Hildebrand solubility parameter $\left(\delta_{\mathrm{H}}\right)$ :

$$
\delta_{H}=\sqrt{\frac{\Delta_{\mathrm{vap}} H-R T}{V_{m}}}
$$

It is the square root of the so-called molar cohesive-energy density $\left(\Delta_{\text {vap }} U=\Delta_{\text {vap }} H-R T\right)$. Again, $\delta_{H}$ does not vary significantly amongst the biodiesels considered (average 17,4 $\pm 0,3\left(\mathrm{~J} / \mathrm{cm}^{3}\right)^{1 / 2}$ ). This property implies that biodiesel could replace some uses of industrial solvents such as benzene, toluene or a mixture of xylenes $\left(\delta_{H} \sim 18\right.$ $\left.\left(\mathrm{J} / \mathrm{cm}^{3}\right)^{1 / 2}\right)$, fossil-derived solvents of great safety concern due to their volatility, toxicity and low flash point.

The traditional meaning of industrial solvent is that of organic liquids used on an industrial scale for the purpose of dissolving, suspending or changing the physical properties of other components of a final product. The selection of an appropriate solvent for a particular formulation is based on the knowledge of the chemical interactions amongst the mixture constituents. Besides thermodynamic considerations such as mutual miscibility, environmental and safety issues orient the substitution of old solvents for newer ones. 


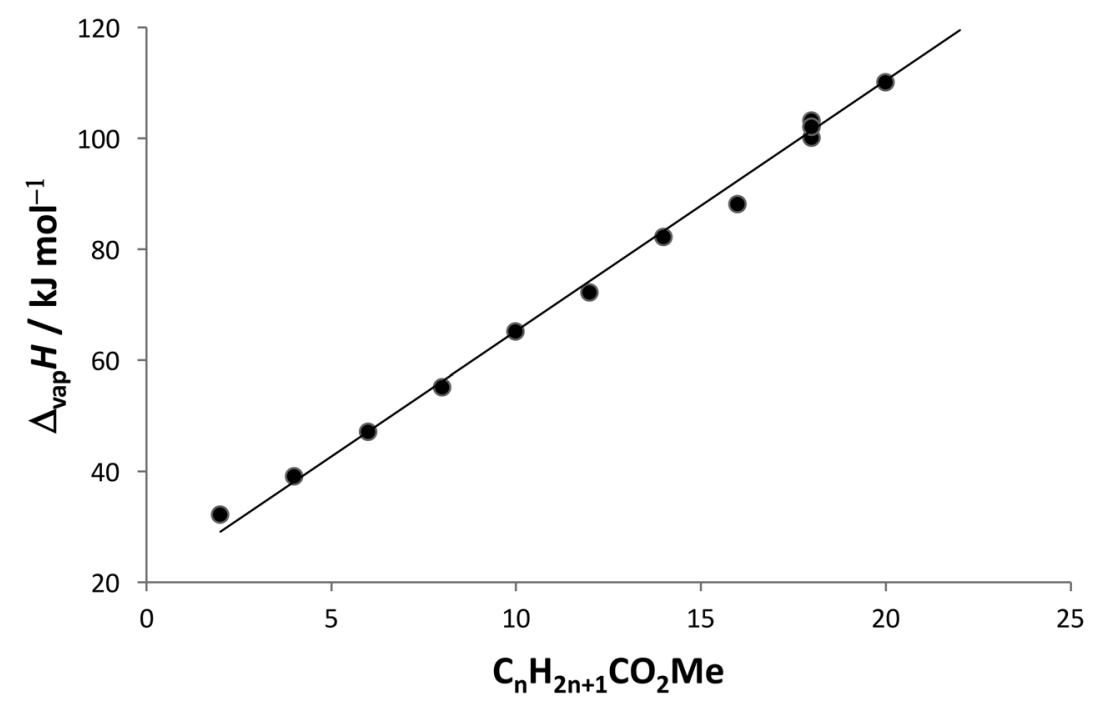

Fig. 1. Effect of chain length on the degree of cohesiveness of methyl esters.

\section{Isothermal compressibility coefficient $\left(\kappa_{\mathrm{T}}\right)$ :}

$$
\kappa_{T}=\frac{-1}{V}\left(\frac{\partial V}{\partial p}\right)_{T}
$$

From the soft-solid model for liquids, one obtains:

$$
\kappa_{T} \approx \frac{\alpha T}{\delta_{H}^{2}}
$$

This quantity is a measure of the resistance to compression. Again, $\kappa_{\mathrm{T}}$ values are similar for all samples, with an average value of $(8,2 \pm 0,7) \times 10^{-10} \mathrm{~Pa}^{-1}$.

The amount of work needed in compressing a substance isothermally and reversibly is determined by $\kappa_{\mathrm{T}}$. $\mathrm{A}$ molecular interpretation of the result obtained is based on the condition that the average distance between molecules in liquids is greater than the corresponding to the potential-energy minimum, and it is similar for molecules of a particular geometry and degree of molecular packing ( $\lambda$ value). Then, it takes similar amounts of work to get the biodiesel systems past the minimum average intermolecular distance.

All biodiesel materials showed $\kappa_{\mathrm{T}}$ values similar to those of mechanical-power transmission fluids in the range from $6 \times 10^{-10} \mathrm{~Pa}^{-1}$ to $8 \times 10^{-10} \mathrm{~Pa}^{-1}$ (Štěpina \& Veselý, 1992). This finding suggests an alternative use of the fatty esters as fluids for transmission of mechanical energy.
Kinematic viscosity $(\mu)$ : Viscosity measures resistance to flow. In mechanical terms, it is considered as the resisting capability of a fluid to gradual deformation by an applied external stress.

Kinematic viscosity (viscosity/density is also called momentum diffusivity) measures transmission of momentum resulting from an applied shear stress.

All biodiesel $\mu$ values vary within a narrow range from $4,6 \mathrm{~mm}^{2} \mathrm{~s}^{-1}$ to $6,97 \mathrm{~mm}^{2} \mathrm{~s}^{-1}$ at $40^{\circ} \mathrm{C}$, except that for Ricinus biodiesel. It is tenable to think that the hydrogen-bonding interaction between sliding Ricinus biodiesel molecular layers provides a less efficient momentum transport mechanism (greater inertia) via hydrogen bonding, thus increasing the specific resistance to flow (Glasstone et al., 1941). This proposed mechanism for momentum diffusion agrees with the high de Guzmán activation energy for viscous flow, $E_{\mu}$. This last rheological parameter gives the effect of temperature on the viscosity of liquids (Atkins \& de Paula, 2006):

$$
\mu \propto e^{\frac{E_{\mu}}{R T}}
$$

Equation [6] indicates that $E_{\mu}$ is the relative change of $\mu$ per unit temperature change, $\left(\frac{\partial \mu / \mu}{\partial T}\right)$. These values are obtained as the slope of graphs of $\ln \mu$ vs. $1 / T$, in an Arrhenius-like fashion.

Figure 2 shows the results for Ricinnus biodiesel. 


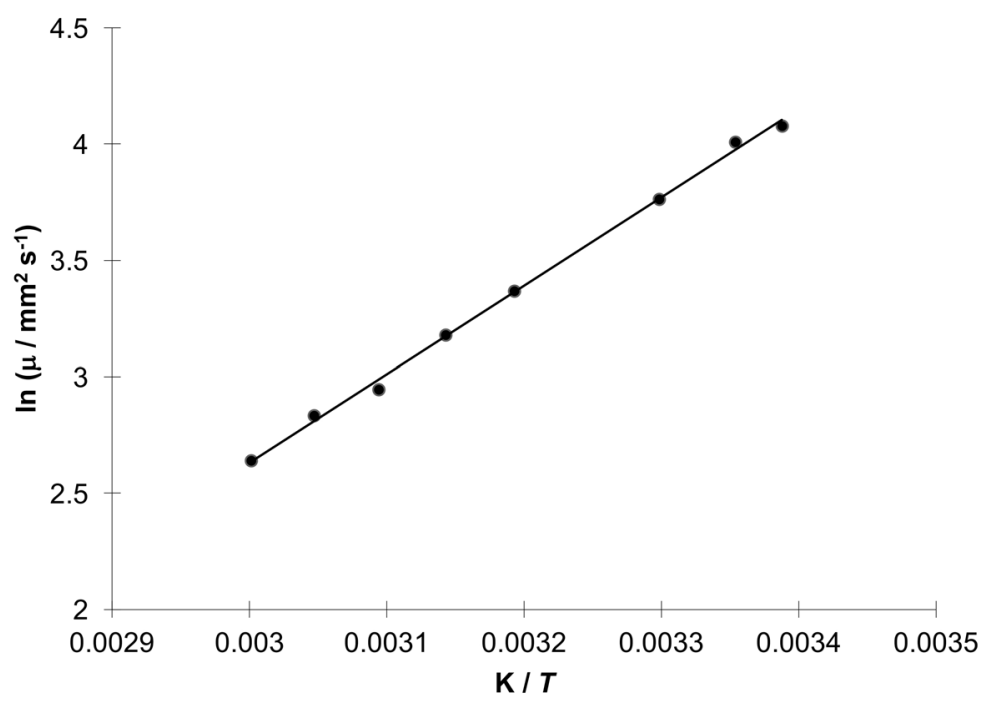

Fig. 2. Temperature dependence of Ricinus biodiesel kinematic viscosity.

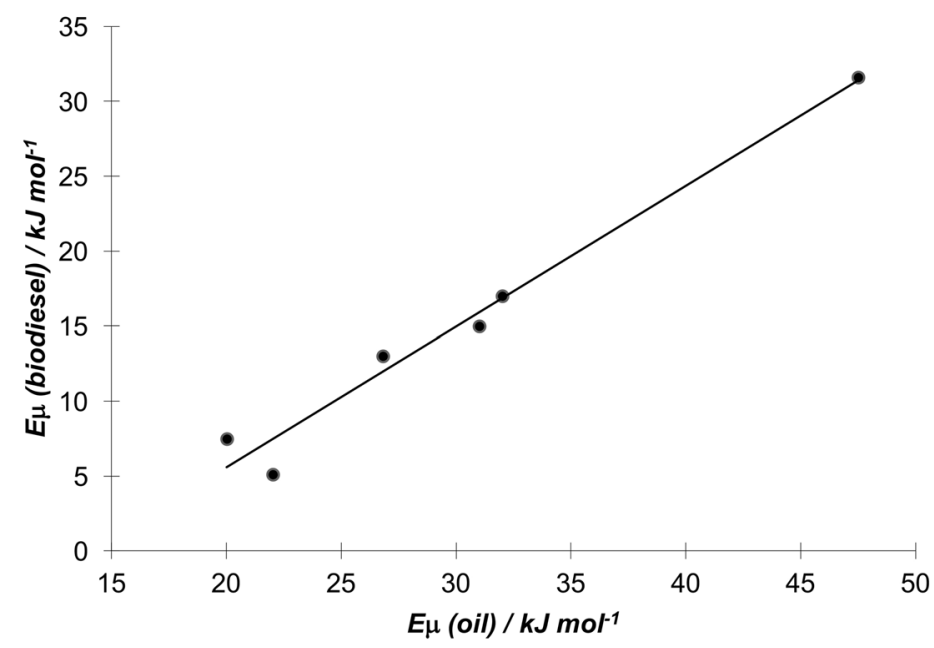

Fig. 3. Correlation between the activation energy for viscous flow of different types de biodiesel and their source vegetable oil.

$E_{u}$ allows the estimation of viscosity values at different temperatures other than that of a standard testing procedure $\left(40^{\circ} \mathrm{C}\right)$. An interesting result is the correlation between the $E_{u}$ values of biodiesels and the corresponding values for their oil feedstocks. Figure 3 shows the result.

The regression equation is:

$$
E_{\mu} \text { (biodiesel) } / \mathrm{kJ} \mathrm{mol}^{-1}=\left[(0,94 \pm 0,08) E_{\mu}(\text { oil }) / \mathrm{kJ} \mathrm{mol}^{-1}\right]-(13 \pm 2) \quad p<0,0002
$$

Equation [7] allows an estimation of the $E_{\mu}$ of a specific type of biodiesel from the viscosity of the parent vegetable oil, before the synthesis an evaluation of the methyl monoester is done.

Biodiesel is a mixture of fatty-acid esters. The polar ester moiety gives a greater degree of attractive intermolecular forces relative to their parent hydrocarbon molecules, as evidenced by their higher average $\Delta_{\text {vap }} H(102 \mathrm{~kJ} / \mathrm{mol})$ vs. $40-50 \mathrm{~kJ} / \mathrm{mol}$ currently accepted for gasoline or petrodiesel (Demirbaş, 2008). Amongst the different fatty-ester mixtures, the carbon chains level out the bulk thermodynamic physical properties of the 
different biomaterials. Thus, no significant differences are found in properties that arise from the intermolecular forces in biodiesel materials.

A salient difference is found in the rheological behaviour of Ricinus biodiesel, due to its mechanism for diffusion of momentum via hydrogen bonding associated to the hydroxyl group attached to carbon 12 of the ricinoleic-acid chains.

Though it might be taken as a lapalissade, it can be concluded that biodiesel materials are useful either as the ester mixture from a single feedstock, or as mixtures from different sources.

\section{REFERENCES}

Alvarado-Montero, H. R. (2012). Estudio y determinación de las propiedades reológicas y termodinámicas del biodiesel metílico y etílico del aceite de las semillas del tempate (Jatropha curcas) como novedosas opciones sustitutivas de derivados del petróleo (master's thesis). University of Costa Rica, San José, Costa Rica

Atkins, P., \& de Paula, J. (2006). Atkin's Physical Chemistry, $8^{\text {th }}$ ed. Oxford: Oxford University Press.

Bártoli, J. A. (2008). Manual para el cultivo de piñón (Jatropha curcas) en Honduras. Centro de Comunicación Agrícola de la Fundación Hondureña de Investigación Agrícola (FHIA), Honduras.

Castellón-Elizondo, E., Lutz, G., \& Mata-Segreda, J. F. (2006). The soft-solid model for liquids. Application to biodiesel and other materials of technological interest. Journal of Physical Organic Chemistry, 19, 744-747. doi:10.1002/ poc. 1068

Chickos, J. S., \& Acree, Jr., W. E. (2003). Enthalpies of vaporization of organic and organometallic compounds. Journal of physical and chemical reference data, 2, 519-878. doi:10.1063/1.1529214

Cristancho, R. J., Hanafi, M. M., Omar, S. R., \& Rafii, M. Y. (2011). Variations in oil palm (Elaeis guineensis Jacq.) progeny response to high aluminium concentrations in solution culture. Plant Biology, 2, 333-342. doi:10.1111/j.1438-8677.2010.00378.x

Demirbaş, A. (2008). Biodegradability of biodiesel and petrodiesel fuels. Energy Sources, Part A: Recovery, Utilization, and Environmental Effects, 31(2), 169-174. doi:10.1080/15567030701521809

Glasstone, S., Laidler, K. J., \& Eyring, H. (1941). The theory of rate processes. New York: Mc Graw-Hill.

Jachmanian, I., Pérez Gomar, E., Villamil, J., \& Villamil, J. J. (2009). El cultivo de tártago (Ricinus comunnis L.) en el Uruguay:
Información preliminar. Boletín de divulgación No. 98. Instituto Nacional de Investigación Agropecuaria, Ministerio de Ganadería, Agricultura y Pesca, República Oriental del Uruguay.

Knothe, G., Dunn, R. O., \& Bagby, M. O. (1997). Biodiesel: The use of vegetable oils and their derivatives as alternative diesel fuels. Fuels and chemicals from biomass, volume 666, chapter 10. Washington, D.C.: American Chemical Society.

Lezcano-González, R. E., \& Mata-Segreda, J. F. (2011). Viscousflow mechanism of \#6 fuel-oil - palm olein mixtures, Ciencia y Tecnología (Costa Rica), 27, 78-83.

Lutz, G.; Chavarría, M., Arias, M. L., \& Mata-Segreda, J. F. (2006). Microbial degradation of palm (Elaeis guineensis) biodiesel. Revista de Biología Tropical, 54(1), 59-63. doi:10.15517/rbt.v54i1.13994

MAG (Ministerio de Agricultura y Ganadería). (1991). Aspectos técnicos sobre cuarentena y cinco cultivos agrícolas de Costa Rica. Dirección General de Investigación y Extensión Agrícola, Ministerio de Agricultura y Ganadería, Costa Rica.

Mittelbach, M., \& Remschmidt, C. (2004). Biodiesel. The comprehensive handbook. Boersedruck, Vienna: Börsedruck $\mathrm{GmbH}$.

Molina, E., Nouel-Borges, G., Sánchez-Blanco, R., RojasCastellanos, J., \& Espejo, M. (2013). Aceite crudo de Attalea butyraceae en dietas para conejos y su efecto sobre consumo, digestibilidad de nutrientes y química plasmática. Livestock Research for Rural Development 25 (11), 1-6.

Monge-Montero, C. (2014). Utilización de los extractos lipídicos del pericarpio y endocarpio del fruto de la palma real (Attalea butyracea) en la preparación de biodiesel con lipasa porcina pancreática como catalizador y lodos residuales procedentes de la producción de aluminio anodizado como un soporte catalítico. Estudio de las propiedades fisicoquímicas y reológicas del biodiesel producido (M. Sc. Thesis). University of Costa Rica, San José, Costa Rica.

Sendzikiene, E., Makareviciene, V., Janulis, P., \& Makareviciute, D. (2007). Biodegradability of biodiesel fuel of animal and vegetable origin. European Journal of Lipid Science and Technology, 109(5), 493-497. doi:10.1002/ejlt.200600243

Smith, N. (2015). Palms and people in the Amazon. Switzerland: Springer International Publishing. doi:10.1007/978-3-319-05509-1

Shoemaker, D. P., \& Garland, C. W. (1968). Experimentos de fisicoquímica. Mexico: UTEHA.

Štěpina, V., \& Veselý, V. (1992). Lubricants and special fluids. Amsterdam: Elsevier. 